\title{
Effect of salt stress on morphology and membrane composition of Lactobacillus acidophilus, Lactobacillus casei, and Bifidobacterium bifidum, and their adhesion to human intestinal epithelial-like Caco-2 cells
}

\author{
Akanksha Gandhi and Nagendra P. Shah ${ }^{1}$ \\ Food and Nutritional Science, School of Biological Sciences, The University of Hong Kong, Pokfulam Road, Hong Kong
}

\begin{abstract}
The effects of $\mathrm{NaCl}$ reduction $(10.0,7.5,5.0,2.5$, and $0 \% \mathrm{NaCl})$ and its substitution with $\mathrm{KCl}(50 \%$ substitution at each given concentration) on morphology of Lactobacillus acidophilus, Lactobacillus casei, and Bifidobacterium longum was investigated using transmission electron microscopy. Changes in membrane composition, including fatty acids and phospholipids, were investigated using gas chromatography and thin layer chromatography. Adhesion ability of these bacteria to human intestinal epithelial-like Caco-2 cells, as affected by $\mathrm{NaCl}$ and its substitution with $\mathrm{KCl}$, was also evaluated. Bacteria appeared elongated and the intracellular content appeared contracted when subjected to salt stress, as observed by transmission electron microscopy. Fatty acid content was altered with an increase in the ratio of unsaturated to saturated fatty acid content on increasing the NaCl-induced stress. Among the phospholipids, phosphatidylglycerol was reduced, whereas phosphatidylinositol and cardioplipin were increased when the bacteria were subjected to salt stress. There was a significant reduction in adhesion ability of the bacteria to Caco-2 cells when cultured in media supplemented with $\mathrm{NaCl}$; however, the adhesion ability was improved on substitution with $\mathrm{KCl}$ at a given total salt concentration. The findings provide insights into bacterial membrane damage caused by $\mathrm{NaCl}$.
\end{abstract}

Key words: potassium chloride substitution, phospholipids, transmission electron microscopy, CaCO-2

\section{INTRODUCTION}

Sodium chloride (table salt) is one of the most important food additives contributing to flavor, texture, and functional properties of food. With increasing awareness about diet and health, numerous attempts

Received December 3, 2015.

Accepted December 30, 2015.

${ }^{1}$ Corresponding author: npshah@hku.hk to reduce salt intake have been undertaken due to the high risk of health diseases associated with high sodium intake (Buemi et al., 2002; Kotchen, 2005; Massey, 2005; Heaney, 2006; Albarracin et al., 2011). Substitution of $\mathrm{NaCl}$ with other salts, such as $\mathrm{KCl}, \mathrm{MgCl}_{2}$, and $\mathrm{CaCl}_{2}$, could potentially reduce sodium chloride intake. Several studies have examined the effect of salt reduction on texture and sensory properties of dairy products (Ayyash and Shah, 2011); however, limited literature exists on the changes in structure and membrane composition of dairy bacteria and their functionality as affected by $\mathrm{NaCl}$ reduction and its substitution with $\mathrm{KCl}$.

In various food processes, bacterial cells are constantly exposed to different kinds of environmental stresses. Depending on the degree of stress encountered, the bacterial cells develop adaptive responses that allow them to survive in unfavorable conditions. The adaptive mechanisms adopted by the bacteria involve gene regulation, which in turn leads to alterations in phenotypical and physiological characteristics. Morphological changes in bacteria that alter the cell shape are associated with the adaptive mechanisms of bacterial survival (Pianetti et al., 2009). The stability and permeability of cellular membranes play a fundamental role in the adaptation of bacteria to environmental stress. These membrane characteristics are closely associated with the membrane lipids and fatty acid composition. As a response to acidic, osmotic, oxidative, and thermal stress, several changes occur in the cell membrane, particularly in the lipids and fatty acids (FA) of the membrane (Murga et al., 2000; Guerzoni et al., 2001).

Furthermore, in addition to their survival and adaptation to the environmental stress, it is important for the bacteria to maintain their functional properties. Adhesion to intestinal cells is considered one of the important selection criteria for probiotics and is a prerequisite for bacterial colonization. Adhesion is also very important for bacterial-host interactions and for the bacteria to be able to confer their health benefits (Bermudez-Brito et al., 2012). The adhesion ability of bacteria largely depends on their membrane proteins (adhesins), which mediate the attachment of bacteria 
to intestinal mucus layer. Furthermore, exposure to environmental stress or any change on the bacterial membrane surface may alter the adhesion of bacteria to the intestinal cells (Buck et al., 2005). However, before investigation of their functional properties in a complex food matrix with environmental stress, it is important to evaluate their stress responses in a less complex media with limited interfering factors. To the best of our knowledge, no study has evaluated the effect of salt stress on adhesion ability of these potential probiotic bacteria. The objectives of our study were to investigate the effects of $\mathrm{NaCl}$ and its substitution with $\mathrm{KCl}$ on the viability, morphology, membrane composition, and adhesion ability to Caco- 2 cell line of 3 potential probiotic bacteria: Lactobacillus acidophilus, Lactobacillus casei, and Bifidobacterium longum.

\section{MATERIALS AND METHODS}

\section{Bacterial Cultivation and Experimental Design}

Lactobacillus acidophilus (CSCC 2400), Lb. casei (ASCC 290), and B. longum (CSCC 5089) were obtained from the Australian Starter Culture Collection (Dairy Innovation Australia, Werribee, Australia) and were stored at $-80^{\circ} \mathrm{C}$. The organisms were activated in sterile de Man, Rogosa, and Sharpe (MRS) broth (Becton Dickinson and Company, Franklin Lakes, $\mathrm{NJ})$ by $1 \%$ (vol/vol) inoculation and then incubation at $37^{\circ} \mathrm{C}$ for $24 \mathrm{~h}$. The activated organisms were used after 3 successive transfers in sterile MRS. The MRS broth was supplemented with various salt concentrations $(10.0,7.5,5.0$, and $2.5 \% \mathrm{NaCl})$, and at each salt concentration $50 \%$ of $\mathrm{NaCl}$ was substituted with $\mathrm{KCl}$. Bacteria were grown individually in MRS broth with and without $\mathrm{NaCl}$ and $\mathrm{KCl}$ for $24 \mathrm{~h}$ at $37^{\circ} \mathrm{C}$ before each analysis, unless stated otherwise.

\section{Bacterial Cell Viability}

Cell viability of all bacteria subjected to varying $\mathrm{NaCl}$ concentrations was determined as described before (Gandhi et al., 2014). Briefly, serial dilutions of each sample were made in sterile peptone water $(0.15 \%$ $\mathrm{wt} / \mathrm{vol}$ ) and were spread on MRS agar plates for $L b$. acidophilus and Lb. casei, and MRS-cysteine agar for B. longum. The plates were incubated for $48 \mathrm{~h}$ at $37^{\circ} \mathrm{C}$ (in anaerobic jar for B. longum) and the colony-forming units were enumerated.

\section{Transmission Electron Microscopy}

The morphological changes in all 3 bacteria were evaluated in the highest $\mathrm{NaCl}$ concentration $(10.0 \%$ wt/vol) and $50 \%$ substitution with $\mathrm{KCl}$ at this salt concentration $(\mathrm{NaCl}: \mathrm{KCl}=1: 1)$. The sections were prepared as described by Pianetti et al. (2009) with some modifications. The 3 bacteria were individually grown in MRS broth containing $0 \% \mathrm{NaCl} / \mathrm{KCl}$ (control), $10.0 \% \mathrm{NaCl}$, and $10.0 \%$ total salt $(5.0 \%$ of each $\mathrm{NaCl}$ and $\mathrm{KCl})$. After $24 \mathrm{~h}$, the cells were centrifuged $(4,000$ $\left.\times g, 10 \mathrm{~min}, 4^{\circ} \mathrm{C}\right)$ and the cell pellet was resuspended in cacodylate buffer $(0.1 M$ sodium cacodylate- $\mathrm{HCl}$ buffer, $\mathrm{pH}$ 7.4). The cell suspension was fixed in equal volume of $2.5 \%$ glutaraldehyde in cacodylate buffer for $8 \mathrm{~h}$ at 4 to $8^{\circ} \mathrm{C}$. Second fixation was performed using $1 \%$ osmium tetroxide $\left(\mathrm{OsO}_{4}\right)$ in cacodylate buffer for 30 min at room temperature $\left(\sim 22^{\circ} \mathrm{C}\right)$. The cell pellet was immersed in $0.5 \mathrm{~mL}$ of prewarmed agar solution. The cell pellets were then subjected to successive dehydration on a rotary shaker as follows: $50 \%$ ethanol for 10 min, $70 \%$ ethanol for $10 \mathrm{~min}, 90 \%$ ethanol for $10 \mathrm{~min}$, $100 \%$ ethanol 3 times, 20 min each, and propylene oxide 2 times, 10 min each. The samples were infiltrated with epoxy resin and propylene oxide mixture (1:1) for $1 \mathrm{~h} 30 \mathrm{~min}$ at $37^{\circ} \mathrm{C}$, followed by infiltration in epoxy resin and propylene oxide mixture $(2: 1)$ overnight at room temperature, and infiltration with fresh epoxy resin for $1 \mathrm{~h} 30 \mathrm{~min}$ at $37^{\circ} \mathrm{C}$ with the help of vacuum oven. Samples were embedded in fresh epoxy resin and polymerized at $60^{\circ} \mathrm{C}$ overnight. Thin sections were cut using a diamond knife and stained with uranyl acetate and lead citrate. The sections, mounted on copper grid, were observed using Phillips CM100 electron microscope (Phillips, Eindhoven, the Netherlands).

\section{Extraction and Analysis of Membrane FA by GC}

Bacterial membrane proteins were removed with the help of proteinase $\mathrm{K}$ for efficient extraction of membrane lipids. The bacteria were grown as described earlier and the cell pellet was collected. The cells were washed twice with PBS buffer ( $\mathrm{pH} 7.4$ ) and resuspended in PBS buffer $(0.5 \mathrm{~g}$ in $0.5 \mathrm{~mL})$. Proteinase $\mathrm{K}(25$ $\mu \mathrm{g} / \mathrm{mL}$, Sigma-Aldrich, St. Louis, MO) was added to the cell suspension in presence of $5 \mathrm{mM}$ dithiothreitol and incubated for $30 \mathrm{~min}$ at $37^{\circ} \mathrm{C}$. An aliquot $(100 \mu \mathrm{L})$ of protease-inhibitor solution was added to stop the protease activity. The protease-inhibitor solution was prepared by dissolving a tablet of EDTA-free protease inhibitor (cOmplete, Roche Applied Science, Penzberg, Germany) in $10 \mathrm{~mL}$ of PBS (pH 7.4). The mixture was then centrifuged $\left(4,000 \times g, 10 \mathrm{~min}, 4^{\circ} \mathrm{C}\right)$ to collect the cell pellet ( $0.5 \mathrm{~g}$ wet weight) for extraction of FA. Membrane FA were extracted and converted to FAME, as described by Sasser (1990). Decanoic acid (C10:0) was used as the internal standard and was added to the cell pellet before extraction and methylation. The ex- 
tracted FA were concentrated by drying under nitrogen and redissolved in GC-grade hexane (Fisher Scientific, Pittsburgh, PA) before analysis.

\section{Separation and Identification of FA by GC-MS}

The separation and identification of FA was performed on a gas chromatograph (Agilent 6590N- 5973N GC-MS system; Agilent, Atlanta, GA) equipped with an Agilent 7694E auto-sampler and a capillary DB-wax column $(30 \mathrm{~m} \AA, 0.25 \mathrm{~mm}$ id, $0.25 \mu \mathrm{m}$ film thickness; J\&W Scientific, Folsom, CA). The injection volume was $1 \mu \mathrm{L}$ (splitless mode) and helium as carrier gas was used at a flow rate of $1 \mathrm{~mL} / \mathrm{min}$. The injector and detector were held at $250^{\circ} \mathrm{C}$. The temperature was increased from $100^{\circ} \mathrm{C}$ (held for $1 \mathrm{~min}$ ) to $190^{\circ} \mathrm{C}$ at a rate of $4^{\circ} \mathrm{C} / \mathrm{min}$, further increased to $235^{\circ} \mathrm{C}$ at a rate of $10^{\circ} \mathrm{C} / \mathrm{min}$, and finally increased to $250^{\circ} \mathrm{C}$ at a rate of $4^{\circ} \mathrm{C} / \mathrm{min}$ (held for $4 \mathrm{~min}$ ). The results were expressed as relative molar percentage (mol \%) for each FA, and the ratio of unsaturated FA to SFA was also calculated (Zhao and Shah, 2014).

\section{Extraction and Profiling by Thin Layer Chromatography}

Enzymatic Digestion of Cell Wall and Cell Surface Proteins. The bacteria were grown as described earlier and the cell pellet was collected after 24 $\mathrm{h}$ and washed twice with sterile distilled water (Zhao and Shah, 2014). Approximately $0.5 \mathrm{~g}$ of cell pellet was suspended in $0.5 \mathrm{~mL}$ PBS ( $\mathrm{pH} 6.2, \sim 0.18 M$ optimal for lysozyme; Dickman and Proctor, 1952) and incubated with lysozyme $(1 \mathrm{mg} / \mathrm{mL}$; Sigma-Aldrich) for $1 \mathrm{~h}$ at $37^{\circ} \mathrm{C}$. The cell pellet was washed with and suspended in $0.5 \mathrm{~mL}$ of PBS ( $\mathrm{pH} 7.4$ ), followed by digestion with proteinase $\mathrm{K}(25 \mu \mathrm{g} / \mathrm{mL})$ in the presence of $5 \mathrm{~m} M$ dithiothreitol (DTT) for $30 \mathrm{~min}$ at $37^{\circ} \mathrm{C}$ as described above. The cell pellet was collected and extraction process was performed under nitrogen to minimize oxidation.

Neutral and Acidic Extraction of Membrane Phospholipids. Two step extraction method was used for efficient extraction of major phospholipids (Özbalci et al., 2013). Neutral extraction was carried out by dissolving the cell pellet (collected after digestion of cell wall proteins) in 1,800 $\mu \mathrm{L}$ of chloroform/methanol (1:2, $\mathrm{vol} / \mathrm{vol}$ ) and gently mixing on a rotor for $60 \mathrm{~min}$ at room temperature (vortex for $1 \mathrm{~min}$ after every $10 \mathrm{~min}$ ). The solution was centrifuged at $10,000 \times g$ for 5 min at $4^{\circ} \mathrm{C}$ and the supernatants were collected in a separate tube. Chloroform $(600 \mu \mathrm{L})$ and $0.8 \% \mathrm{NaCl}$ solution $(1 \mathrm{~mL})$ were added to the supernatant and mixed for $1 \mathrm{~min}$ using a vortex. The solution was centrifuged at 5,500 $\times g$ for 5 min at $4^{\circ} \mathrm{C}$ and the lower organic phase was collected in a glass tube.

For acidic extraction, the cell pellet was resuspended in $1 \mathrm{~mL}$ chloroform/methanol/37\% $\mathrm{HCl}$ (40:80:1, vol/ vol) and gently mixed on a rotor for $30 \mathrm{~min}$ at room temperature (vortex for $30 \mathrm{~s}$ every $5 \mathrm{~min}$ ). The tubes were transferred to ice and $250 \mu \mathrm{L}$ of cold chloroform and $450 \mu \mathrm{L}$ of cold $0.1 \mathrm{~N} \mathrm{HCl}$ were added to each tube. The solution was mixed for 1 min using a vortex, and centrifuged at $5,500 \times g$ for $5 \mathrm{~min}$ at $4^{\circ} \mathrm{C}$. The chloroform-rich phase from neutral and acidic extraction was pooled in a glass tube and dried under an $\mathrm{N}_{2}$ stream. The weight of dried lipids was determined and stored in chloroform/methanol (90:10, vol/vol; $50 \mathrm{mg} / \mathrm{mL})$ at $-20^{\circ} \mathrm{C}$ until analysis.

\section{Separation of Phospholipids by High-Performance Thin Layer Chromatography}

Silica gel 60 thin-layer chromatographic plates (Merck, Darmstadt, Germany) were oven activated for overnight at $100^{\circ} \mathrm{C}$ before use. The plates were developed with developing solvent before spotting to remove impurities from the adsorbent layer. A filter paper was placed in the developing chamber which was then saturated with the developing solvent for $15 \mathrm{~min}$. Phospholipids were separated on thin layer chromatography plates using chloroform/methanol/acetic acid/water (71:20:6.25:2.5, $\mathrm{vol} / \mathrm{vol}$ ) as the mobile phase. The bands were visualized by spraying with the following reagents: (1) $0.5 \%$ (wt/ vol) vanillin in ethanol/concentrated $\mathrm{H}_{2} \mathrm{SO}_{4}(97: 3$, vol/ vol) solution for all polar lipids (Rakhuba et al., 2009) and (2) ammonium molybdate/perchloric acid reagent for phospholipids (Nzai and Proctor, 1998). The bands detected with vanillin were much sharper in color and were scanned using Molecular Imager XR+ System (Bio-Rad, Hercules, CA), and analyzed in Image Lab (version 4.0, Bio-Rad). The relative quantity of each phospholipid was determined based on the density of the bands. The major phospholipids were identified by comparing the relative mobility of phospholipid standards and the lipid bands detected in samples. The following standard phospholipids (Sigma-Aldrich) were prepared by dissolving in chloroform/methanol (90:10, $\mathrm{vol} / \mathrm{vol}$ ) and used for identification: cardiolipin (CL), phosphatidylcholine (PC), lyso-phosphatidylcholine (LPC), phosphatidylethanolamine (PE), phosphatidylglycerol (PG), and phosphatidylinositol (PI).

\section{Cell Line}

The human intestinal epithelial-like Caco-2 cell line was obtained from the American Type Culture Collec- 
tion (ATCC, Manassas, VA). The cells were maintained and cultured in Difco's minimum essential medium (DMEM; Gibco BRL, Life Technologies, Grand Island, NY) supplemented with $10 \%$ fetal bovine serum and $1 \%$ mixture of penicillin-streptomycin solution (Gibco $\mathrm{BRL}$ ). The cells were incubated at $37^{\circ} \mathrm{C}$ in a humidified incubator (US Air Flow-NuAire, Plymouth, MN) in an atmosphere of $5 \% \mathrm{CO}_{2}$ and $95 \%$ air. All cells used in this study were between 32 and 37 passages. Cells were subcultured at $80 \%$ confluence by trypsinization (0.25\% trypsin-EDTA, Gibco BRL).

\section{Determination of Adhesion Ability}

The adhesion ability of bacteria to Caco- 2 cells was measured by the cell adhesion assay as per the method of Parkar et al. (2008) with some modifications. Briefly, Caco-2 cells were seeded at approximately $1 \times 10^{4}$ cells per well in 12-well plates and incubated to obtain confluence before the assay (10-12 d). Bacteria were grown in MRS broth supplemented with varying salt concentrations as described earlier. The bacterial cell pellet was washed with PBS buffer $(\mathrm{pH} 7.2)$ and resuspended in antibiotic-free DMEM at a cell density of approximately $10^{9} \mathrm{cfu} / \mathrm{mL}$. The cell line monolayer was washed twice with PBS buffer to remove interference of antibiotics. The bacterial cell suspension was added to each well (100:1 bacteria:Caco-2 cells) and incubated at $37^{\circ} \mathrm{C}$ for $2 \mathrm{~h}$. After the incubation period, the supernatant was removed and wells were gently washed with PBS to remove any nonspecifically bound bacteria. The Caco-2 monolayers were then trypsinized by addition of $0.25 \%$ trypsin-EDTA solution and the viable bacteria in each well were counted using appropriate agar plates as described earlier. Adhesion ability was expressed as percentage of bacteria adhered compared with the control using the following equation:

$$
\begin{gathered}
\text { Relative adhesion ability }(\%)= \\
{\left[\left(\mathrm{CFU}_{\mathrm{S}} / \mathrm{CFU}_{\mathrm{C}}\right) \times 100\right],}
\end{gathered}
$$

where, $\mathrm{CFU}_{\mathrm{S}}$ is the number of stressed bacterial cells adhered to Caco-2 cell lines and $\mathrm{CFU}_{\mathrm{C}}$ is the number of normal bacteria adhered to Caco- 2 cell lines.

\section{Statistical Analysis}

All experiments were replicated thrice and all analyses were carried out in duplicate. The data obtained were analyzed using one-way ANOVA at $95 \%$ level of significance using SPSS statistics software v 20.0 (IBM Inc., Armonk, NY). Post hoc analysis was performed to further investigate the difference between the means at different $\mathrm{NaCl}$ and $\mathrm{KCl}$ concentrations (Oliveira et al., 2012).

\section{RESULTS AND DISCUSSION}

\section{Bacterial Cell Viability}

The effect of $\mathrm{NaCl}$ reduction and substitution on the viable cell count $\left(\log _{10} \mathrm{cfu} / \mathrm{mL}\right)$ of bacteria is shown in Figure 1. An increase in $\mathrm{NaCl}$ concentration was inversely associated with the cell viability for all the 3 bacteria. Among the 3 bacteria, $B$. longum was the most affected by salt stress. The lowest viable cell count of $B$. longum was observed to be about $3 \log _{10} \mathrm{cfu} / \mathrm{mL}$ when exposed to $10.0 \% \mathrm{NaCl}$, whereas Lb. acidophilus and $L b$. casei showed a significant $(P<0.05)$ reduction only after exposure to higher $\mathrm{NaCl}$ concentrations (7.5 and $10.0 \%)$. At a given salt concentration, substitution with $\mathrm{KCl}(50 \%)$ increased the viable cell count as compared with that of the bacteria grown in medium supplemented with only $\mathrm{NaCl}$. The effect of substitution with $\mathrm{KCl}$ was more distinctly observed at higher total salt concentrations (7.5 and 10.0\%). Viability of bacteria in stress environment is crucial for functionality of the bacteria in dairy products, particularly those containing high levels of salt or low moisture. Reduced viable count of bacteria was observed on increased exposure to salt stress, possibly owing to the injury caused by salt to the integrity of the bacterial membrane (Gandhi and Shah, 2015). However, $\mathrm{KCl}$ substitution relatively improved the cell growth indicative of the protective effect of potassium chloride.

\section{Transmission Electron Microscopy}

The morphological changes in the bacterial cells, owing to their growth in media supplemented with salt, were observed by transmission electron microscope (Figure 2). Elongation of bacterial cells grown at 10.0\% $\mathrm{NaCl}$ (Figure 2b) was observed for all bacteria and was most distinctly observed in Lb. acidophilus and B. longum. For bacteria grown in media supplemented with $10.0 \% \mathrm{NaCl}$, the cell structure was irregular and the membrane showed several deformities. On observing through transmission electron microscopy, the cytoplasmic content appeared coagulated due to salt stress. On the other hand, for the bacteria grown in media supplemented with $10.0 \%$ total salt $(5.0 \%$ of each $\mathrm{NaCl}$ and $\mathrm{KCl}$; Figure 2c), these morphological changes were less distinct as compared with the control $(0 \% \mathrm{NaCl} /$ $\mathrm{KCl}$; Figure 2a), possibly owing to the protection offered by $\mathrm{KCl}$.

Morphological changes in microorganisms are visible indicators of their adaptation to environmental stress 

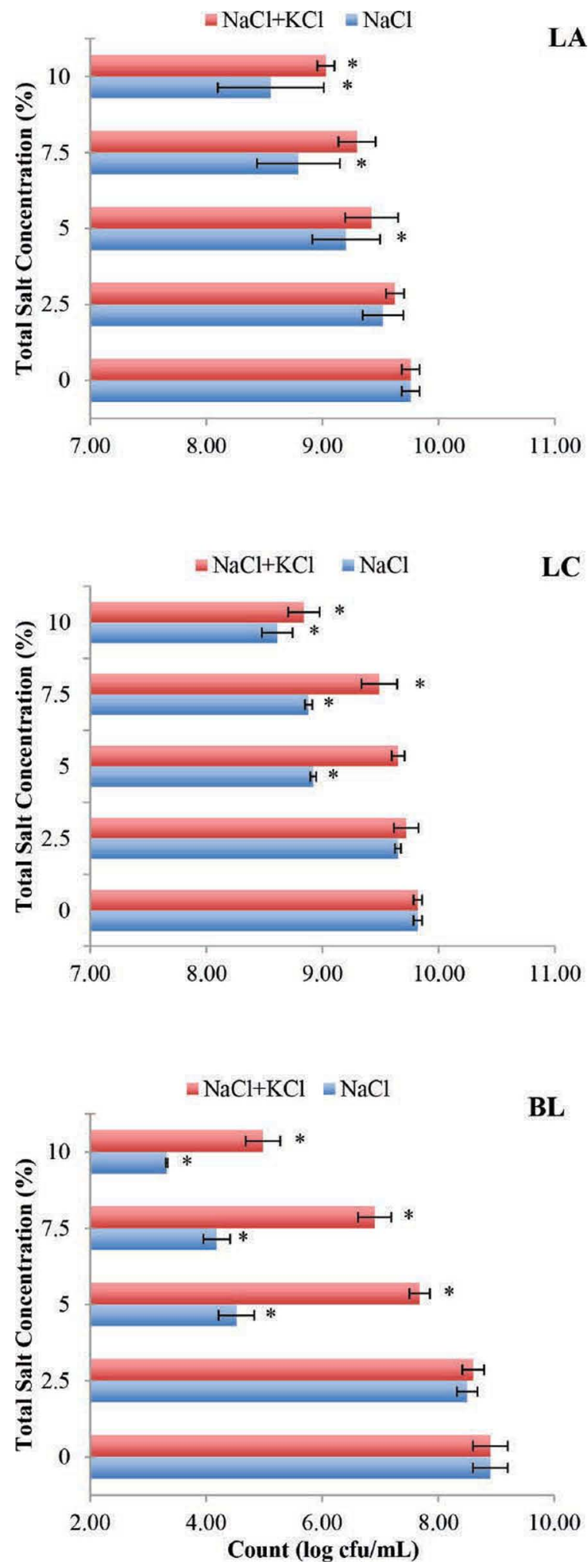

Figure 1. Effect of $\mathrm{NaCl}$ reduction and substitution with $\mathrm{KCl}$ on viable cell count $\left(\log _{10} \mathrm{cfu} / \mathrm{mL}\right)$. Values are means $\pm \mathrm{SE}$ of at least 3 replicates $(\mathrm{n} \geq 3)$. An asterisk $(*)$ means values are significantly different $(P<0.05)$ from control $(0 \%) . \mathrm{LA}=$ Lactobacillus acidophilus; $\mathrm{LC}=$ Lactobacillus case $; \mathrm{BL}=$ Bifidobacterium longum. Color version available online. and transmission electron microscopy is a powerful technique to observe such changes in bacterial cells. At high $\mathrm{NaCl}$ concentrations (10.0\%), elongation of bacterial cells was observed, which is considered as a means of adaptation of the bacteria to unfavorable environmental conditions (McMahon et al., 2007). Elongation of the bacterial cell caused by adaptation to salt stress may be due to several reasons. Low water activity, possibly due to addition of salt in this case, is reported to affect DNA supercoiling, thereby altering the regulation of genes involved in cell division leading to filamentation (Graeme-Cook et al., 1989). The other possible mechanism may be due to the role of cellular turgor pressure during cell division (Csonka and Hanson, 1991), which explains that osmotic stress may alter the degree of cell hydration causing a lack of signals for cells to divide. Substitution of $\mathrm{NaCl}$ with $\mathrm{KCl}$ proved to be less stressful for the bacteria, as observed by the higher density of the cytoplasmic content and reduced elongation and irregularities in the cell membrane. This may be due to the weaker bonding of potassium ions to the membrane as compared with the sodium ions (Gurtovenko and Vattulainen, 2008), leading to reduced alterations in the cellular membrane.

\section{FA Composition by GC}

The relative percentages of major FA and the ratios of unsaturated to saturated FA (U/S) are presented in Figures 3 and 4, respectively. The FA content of the bacteria was altered due to exposure to salt stress. In all the 3 bacteria, a decrease in C14:0 was observed with increasing $\mathrm{NaCl}$ concentration; however, substitution with $\mathrm{KCl}$ increased the relative percentage of C14:0. Conversely, C16:0, the most abundant FA, was higher in bacteria subjected to high salt concentration. In general, the U/S ratio (Figure 4) increased at higher salt levels $(7.5 \%)$; however, a slight decline in U/S was observed at $10.0 \%$ salt concentrations. The $\mathrm{U} / \mathrm{S}$ ratio increased on substitution with $\mathrm{KCl}$ at a specific salt concentration. Lactobacillus casei showed the least difference (almost 1-fold increase) in U/S upon substitution at higher concentration (10.0\%), whereas B. longum increased about 1.5 times on substitution. The increase in the U/S ratio when the bacteria were subjected to salt stress could be attributed to the increase in the degree of FA unsaturation as an adaptive measure. The trend of U/S ratio for $L b$. casei was slightly different as compared with the other 2 bacteria, which may be indicative of its resistance to lower salt concentrations $(2.5 \%)$.

Fatty acids are the major constituents of membrane glycerolipids, and the distribution of unsaturated FA and SFA and the fatty acyl chain conformation af- 


\section{LA- (a)}

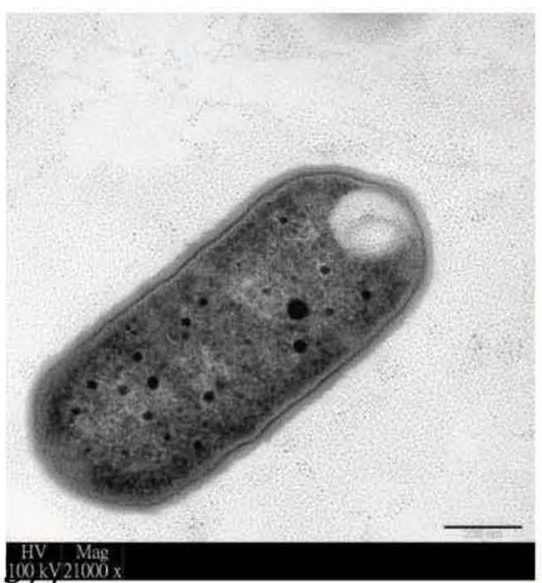

LC- (a)

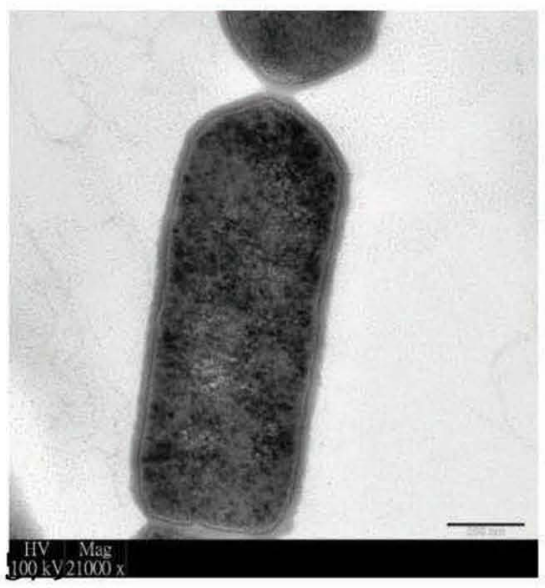

BL- (a)

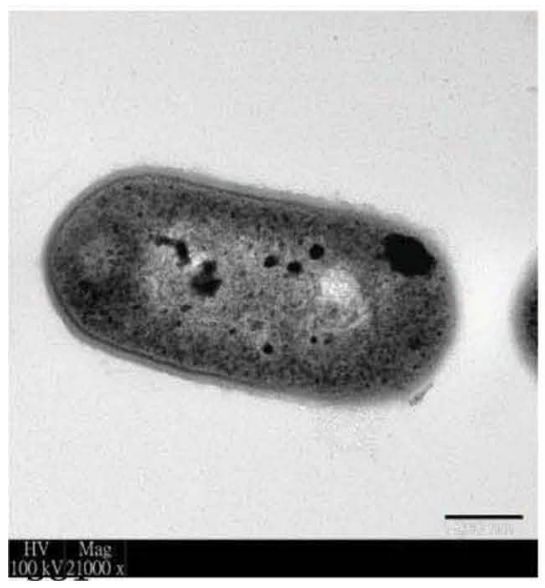

LA- (b)

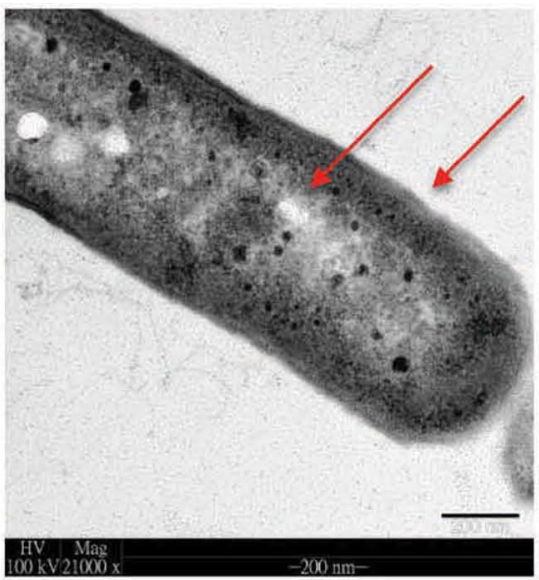

LC- (b)

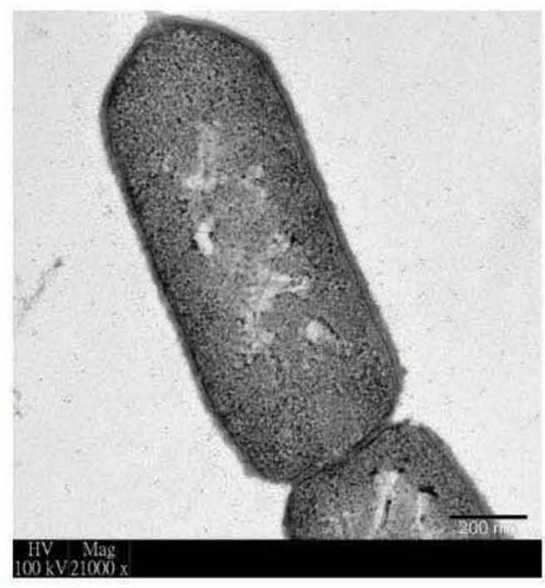

BL- (b)

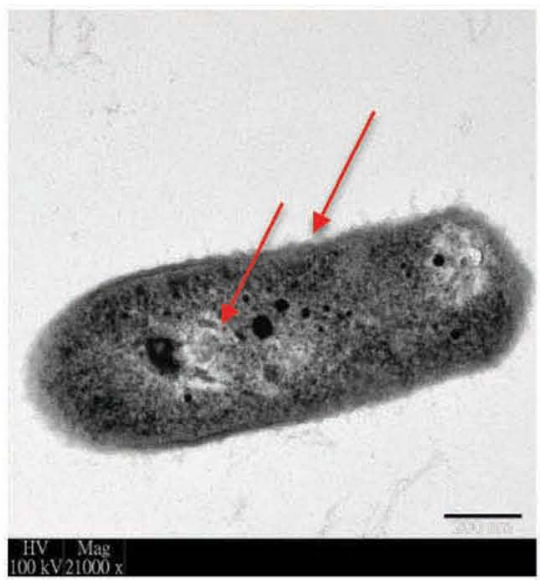

LA- (c)

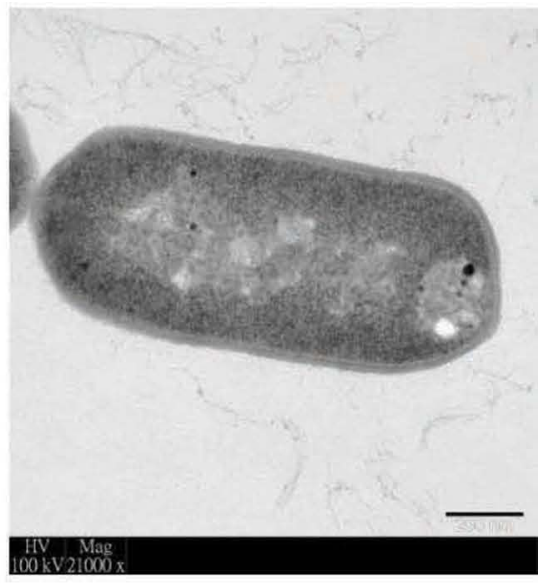

LC- (c)

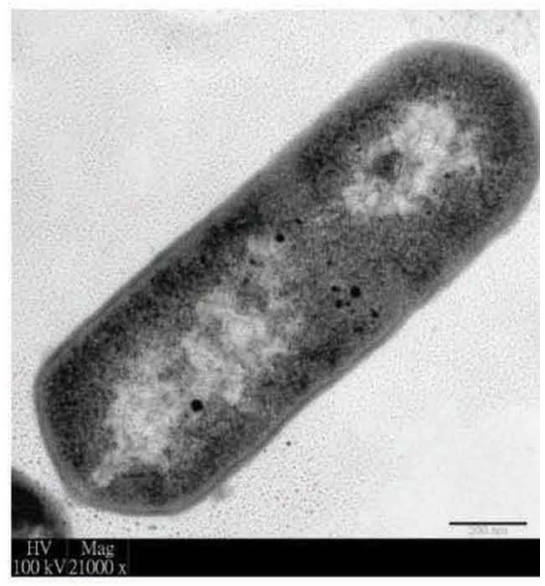

BL- (c)

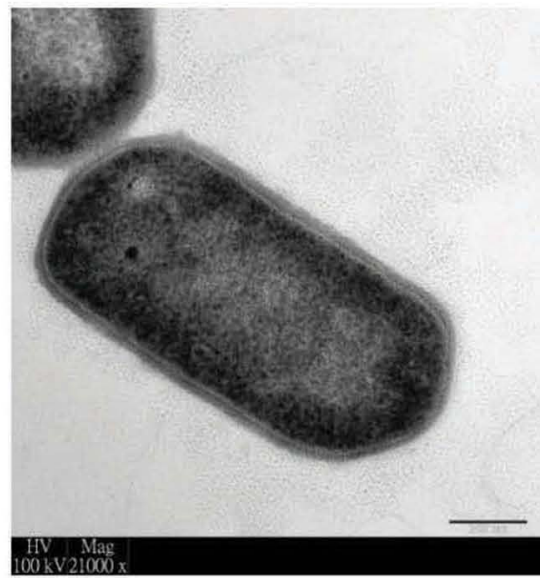

Figure 2. Transmission electron micrographs (TEM) of thin sections of bacteria grown in (a) de Man, Rogosa, Sharpe broth (MRS), (b) MRS $+10.0 \% \mathrm{NaCl}$, and (c) MRS $+10.0 \%$ total salt $(5.0 \%$ each of $\mathrm{NaCl}$ and $\mathrm{KCl}$ ). Magnification of micrographs is 21,000 fold (black bars below are $200 \mathrm{~nm}$; representative micrographs of bacteria in different conditions). LA = Lactobacillus acidophilus; LC = Lactobacillus casei; $\mathrm{BL}=$ Bifidobacterium longum. Arrows indicate membrane irregularities and shrinkage of cytoplasmic contents. Color version available online. 


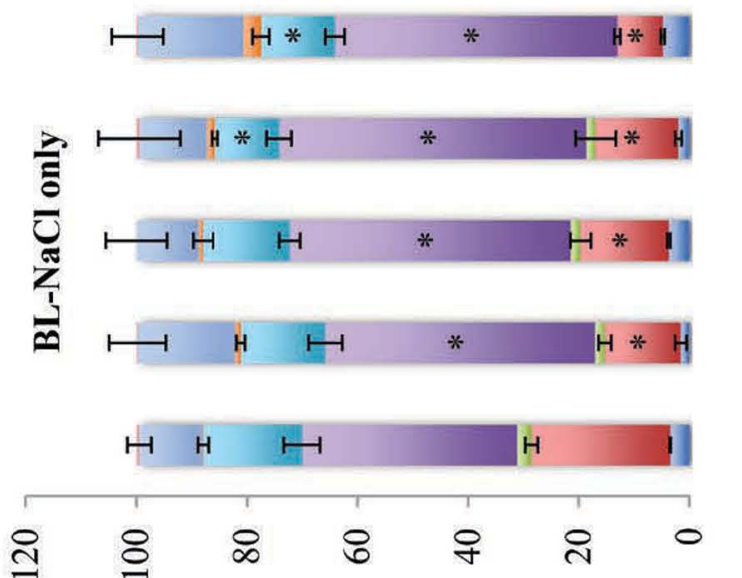

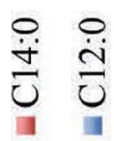

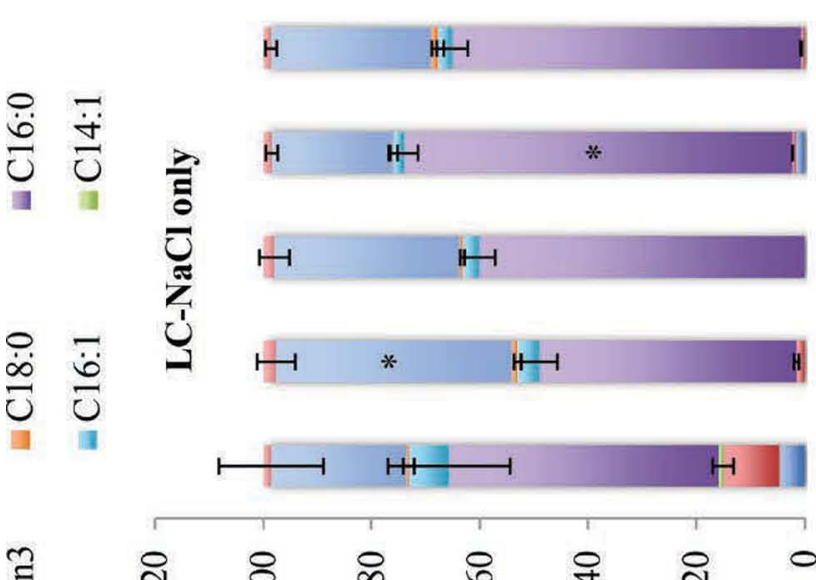

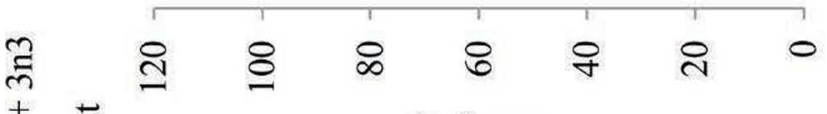

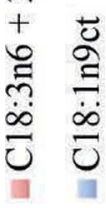

(\%) jou

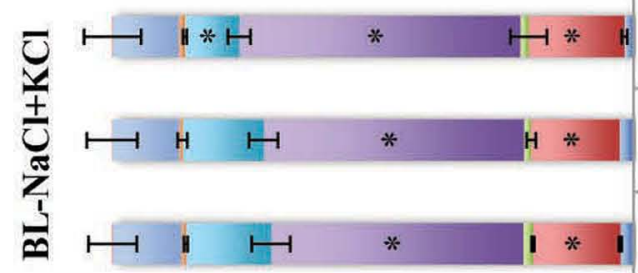

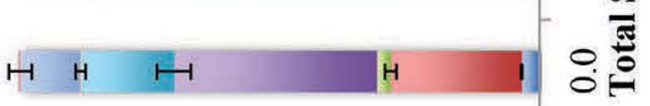

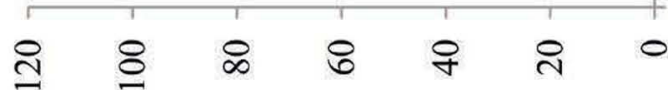

(\%) Iow

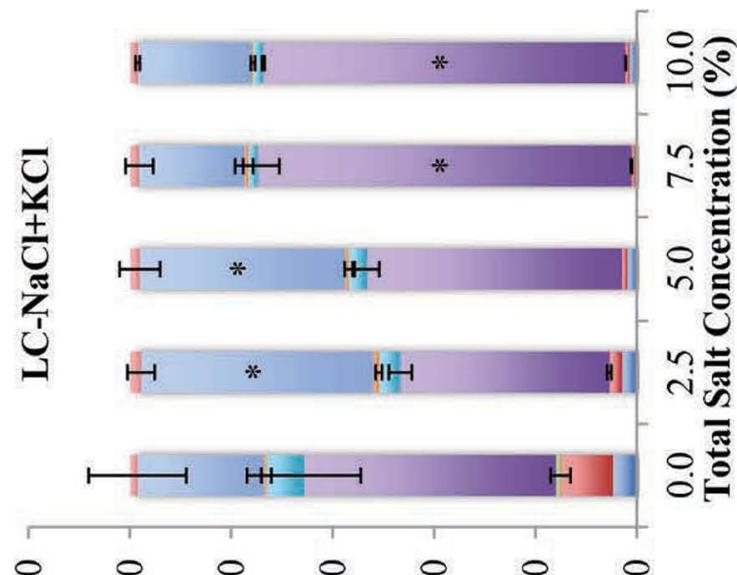

고 8 \& 8 잉

(\%) [ouI

H H*H
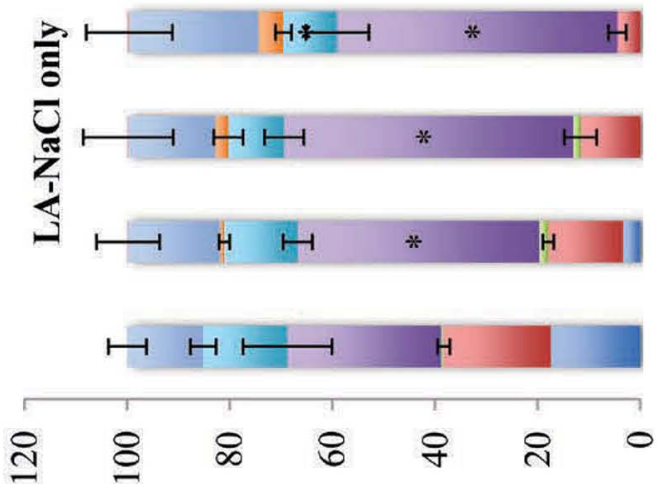

(\%) jou

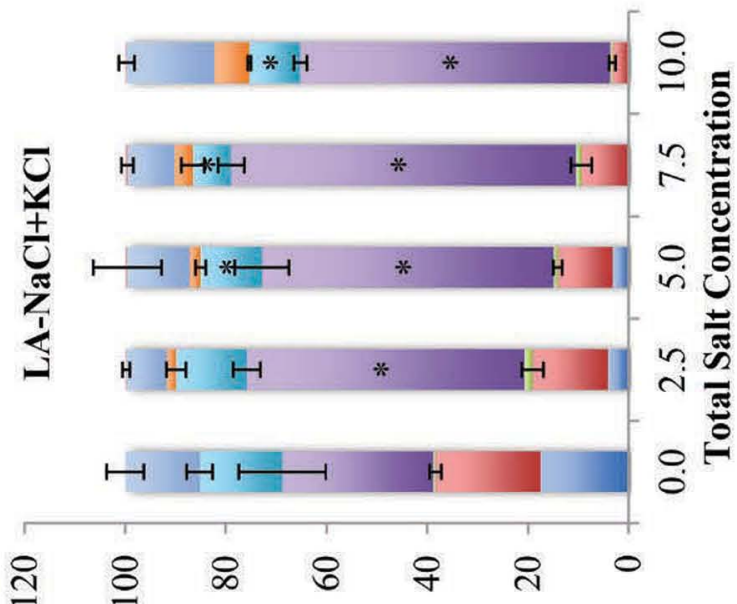

(\%) [ou 
fects the membrane fluidity. The physical properties of bacteria, for instance membrane fluidity, are directly correlated with the level of unsaturated FA in the membrane (Szalontai et al., 2000). Bacterial cells regulate the membrane FA to adapt to the environmental stress; change in the U/S ratio is the most commonly observed mechanism in cells to modulate membrane fluidity. It has been shown that successful adaptation of bacteria to environmental stress conditions, such as acid stress ( $\mathrm{Wu}$ et al., 2012), bile stress (Kimoto-Nira et al., 2009), and cold stress (Wang et al., 2005), increases the U/S ratio.
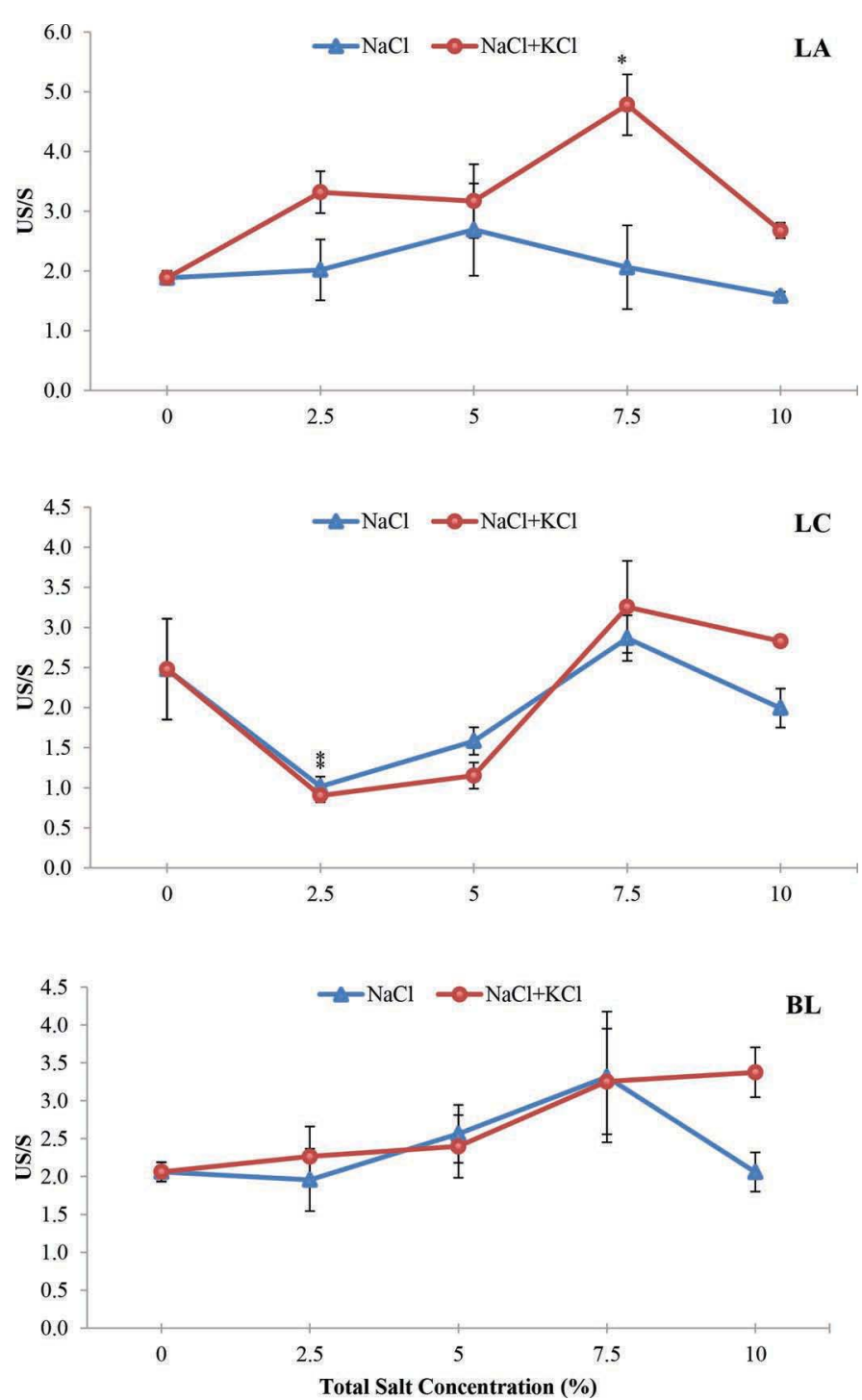

Figure 4. Profiles of unsaturated fatty acid-to-SFA ratio (US/S) as affected by $\mathrm{NaCl}$ reduction and substitution with $\mathrm{KCl}$. Values are means \pm SE of 3 replicates $(\mathrm{n}=3)$. An asterisk $(*)$ means values are significantly different $(P<0.05)$ from control $(0 \%)$. LA $=$ Lactobacillus acidophilus; $\mathrm{LC}=$ Lactobacillus case $; \mathrm{BL}=$ Bifidobacterium longum. Color version available online.
Studies have also correlated an increase in presence of unsaturated FA with a decrease in responsiveness of the stress response promoter element-driven gene to heat and salt stress (Chatterjee et al., 2000). Furthermore, the changes in FA unsaturation may be linked with the stress response proteins in the bacteria (Török et al., 1997). The findings from our study present further support the hypothesis of Chatterjee et al. (2000) and Guerzoni et al. (2001) that FA unsaturation is possibly involved in stress signal transduction, thereby affecting the bacterial stress response mechanisms.

\section{Phospholipid Composition by Thin Layer Chromatography}

The changes in the phospholipids were evaluated using thin layer chromatography and quantified based on the intensity of the bands (Figure 5). Phosphatidylglyercol was the major phospholipid present in the bacterial cells. Cardiolipin and PI contents increased in $L b$. acidophilus and Lb. casei when subjected to $10.0 \%$ $\mathrm{NaCl}$ concentration. These findings are similar to those observed by López et al. (2000), where PG content decreased and CL increased when Bacillus subtilis was grown in hypertonic medium, suggesting that increase in CL acts as a barrier against high ionic level. An increase in PI was observed in B. longum when subjected to higher salt concentrations (10.0\%); however, CL content was not affected by substitution in Bifidobacterium. The most significant $(P<0.05)$ change in PI was observed in $L b$. casei with increasing salt concentration. In general, no significant changes were observed in less abundant phospholipids (PE, LPC, and PC).

Owing to the closely related cross-regulation between the different membrane components, dramatic alteration in individual constituents may affect the cell membrane, thereby causing cell death. The membrane phospholipids are the most adaptable molecules in response to environmental stress. Stability of membrane depends on the stability of the lipid bilayer conformation that depends on the geometrical shape of the lipids. When exposed to salt stress, bacteria respond by alterations in the phospholipid composition. In all the 3 bacteria the most abundant phospholipid was PG, and thus the lipid bilayer was more negative due to higher concentration of PG (anionic) as compared with PC (zwitterionic). However, when subjected to salt stress the content of PG was reduced in all bacteria, whereas PC remained unaffected and PI and CL were increased in all bacteria. This shift in the membrane lipid metabolism toward the reduced synthesis of anionic phospholipids may reduce the electrostatic repulsion between the lipid bilayer and outer media environment 

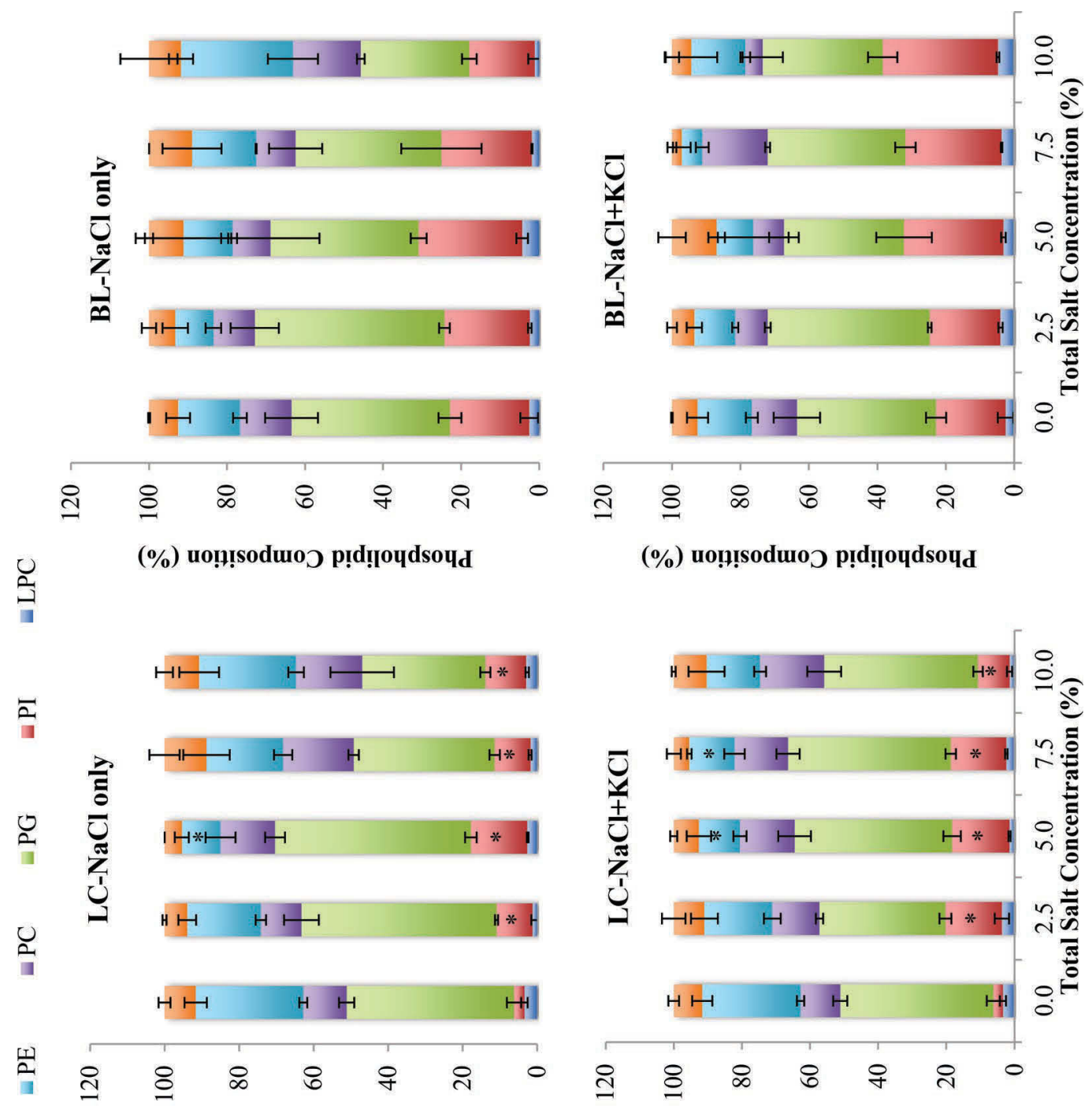

(\%) uo!!!soduoว p!d!̣loudsoYd

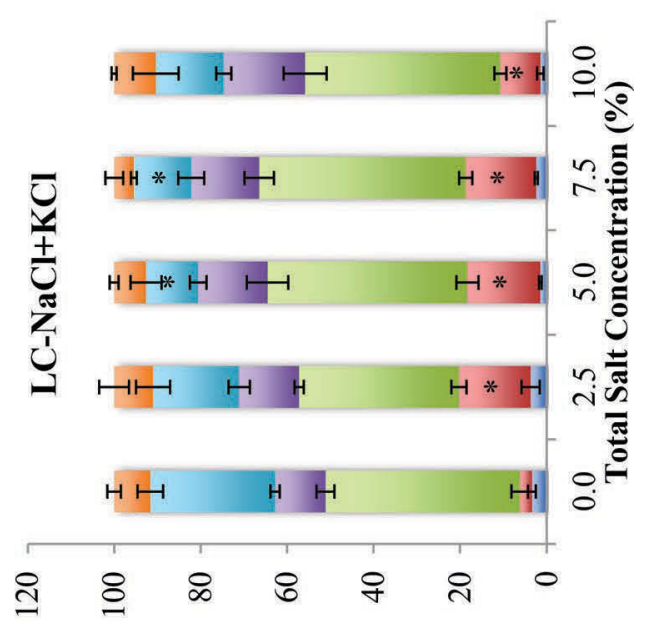

(\%) uo!̣!sodwo p p!d!̣oudsoपd

(\%) uo!!!sodwo p!d!!oudsoud

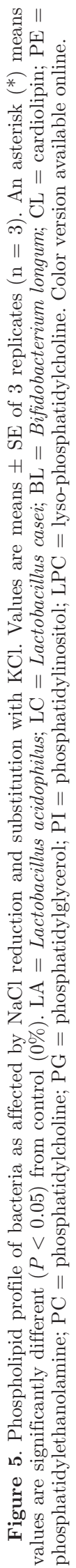


(Lewis and McElhaney, 2000), which could be attributed to the adaptive response of the bacteria to salt stress. An important component of osmotic tolerance is restoration and stabilization of the bacterial membrane lipid bilayer phase, which is attained by an increase in anionic lipids and a decrease in zwitterionic lipids (Beales, 2004). The negative charge on the surface of the membrane increases and thus, an increase of positively charged molecules occurs near the surface (Lee, 2004). This change is important for osmotic adaptation of bacterial cells, as the first stress response in bacteria is the uptake of $\mathrm{K}^{+}$into the cytoplasm (McLaggan et al., 1994).

\section{Adhesion Ability to Caco-2 Cell Line}

The bacteria were examined for their adhesion ability to human intestinal epithelial-like Caco-2 cells, as affected by varying $\mathrm{NaCl}$ and $\mathrm{KCl}$ concentrations (Figure 6). The adhesion ability of stressed bacteria was expressed as a percentage of the control (bacteria grown in $0 \% \mathrm{NaCl}$ ). In general, the adhesion ability of all 3 bacteria decreased when subjected to salt stress. The least adhesion was observed at $10.0 \% \mathrm{NaCl}$, which was observed to be $52 \%$ for $L b$. case $i$ and approximately $40 \%$ for Lb. acidophilus and B. longum. However, at a particular total salt concentration, substitution with $\mathrm{KCl}$ increased the adhesion ability of all bacteria. The increased effect of substitution was observed at higher total salt concentration $(10.0 \%)$; highest adhesion ability was at $7.5 \%$ total salt $(3.75 \%$ of each $\mathrm{NaCl}$ and $\mathrm{KCl}$ ) for $L b$. casei and Lb. acidophilus, which was almost double of the percentage adhesion of bacteria grown in $7.5 \% \mathrm{NaCl}$ only. Significant $(P<0.05)$ reductions in adhesion ability of $L b$. acidophilus and $B$. longum were noted at all salt concentrations, whereas in $L b$. casei the adhesion ability was significantly $(P$ $<0.05$ ) reduced when subjected to salt concentrations higher than $5.0 \%$. Among the 3 bacteria, the adhesion ability of $L b$. casei was the highest at all $\mathrm{NaCl}$ and $\mathrm{KCl}$ concentrations.

Human intestinal epithelial-like Caco-2 cell line is a well-characterized colon carcinoma cell line that has been extensively used to study the organization and function of human intestinal cells in vitro. With proper cultivation, spontaneous differentiation, and formation of polarized epithelial cell monolayer, Caco-2 cells mimic the mature enterocyte lining of the small intestine functionally and morphologically (Sambuy et al., 2005). Bacterial adhesion to epithelial intestinal cells is important to prevent immediate washout of bacteria by peristalsis, and thus for colonization by microorganisms (Falkow et al., 1992). Bacterial adhesion is also likely to be involved in competitive exclusion of enteropathogens and immunomodulation of the host (Plant and Conway, 2002; Lee et al., 2003).

The adhesion ability of stressed bacteria to Caco-2 cells varied with the organism. In general, the adhesion ability of the bacteria was reduced when grown in media supplemented with $\mathrm{NaCl}$. On the other hand, substitution with $\mathrm{KCl}$ increased the adhesion ability at a given total salt concentration as compared with only with $\mathrm{NaCl}$. This may be due to weaker bonding of $\mathrm{KCl}$ ions to the cell membrane as compared with the stronger bonding of $\mathrm{NaCl}$ ions (Gurtovenko and Vattulainen,
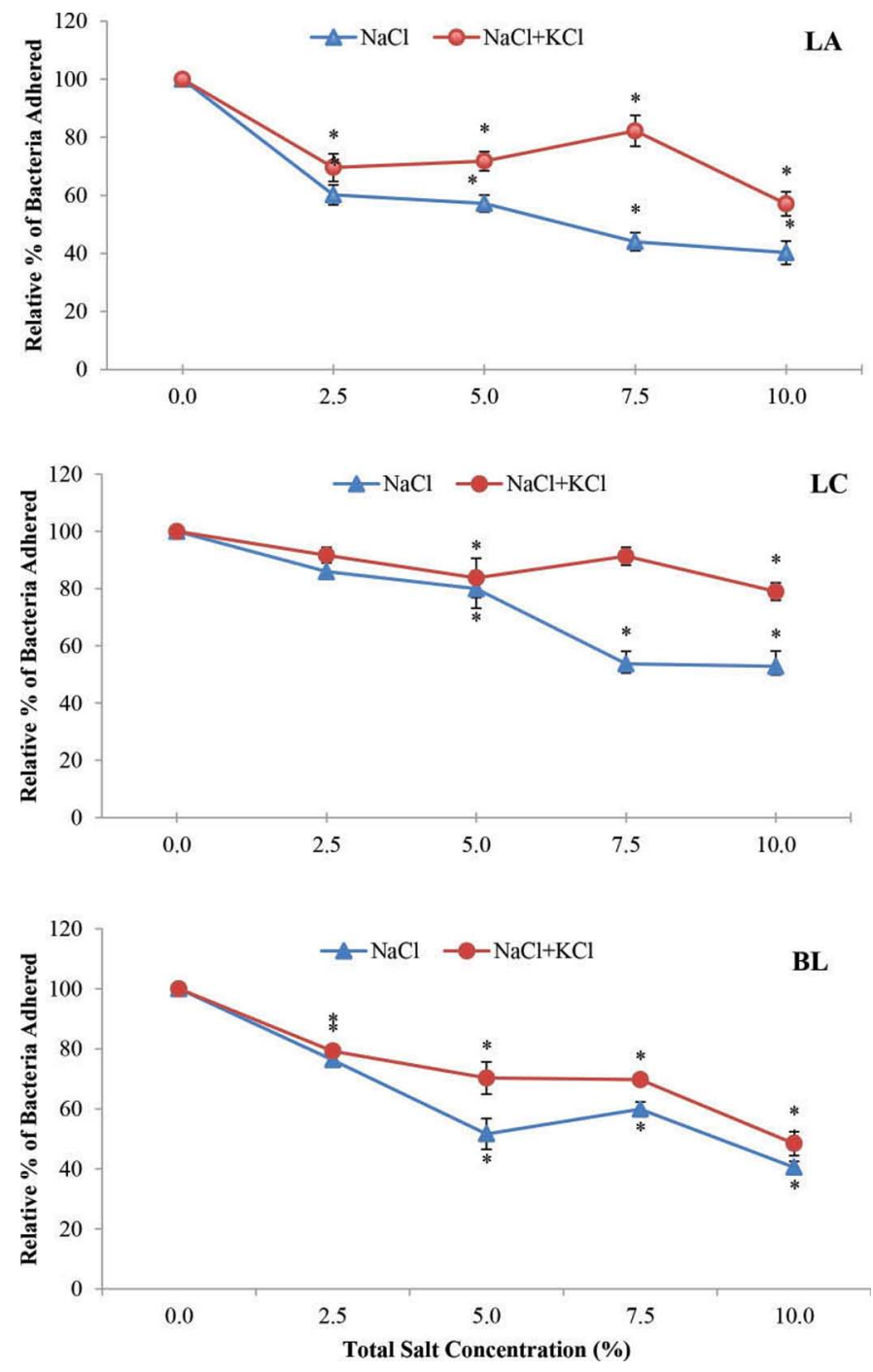

Figure 6. Effect of $\mathrm{NaCl}$ reduction and substitution with $\mathrm{KCl}$ on adhesion ability of bacteria to Caco-2 cells. Values expressed as percentage of control $(0 \%)$. Values are means \pm SE of 3 replicates $(\mathrm{n}=$ $3)$. An asterisk $(*)$ means values are significantly different $(P<0.05)$ from control $(0 \%) . \mathrm{LA}=$ Lactobacillus acidophilus; $\mathrm{LC}=$ Lactobacillus case $;$ BL $=$ Bifidobacterium longum. Color version available online. 
2008). Lactobacillus casei 290 was found to be the most adherent bacteria at all $\mathrm{NaCl}$ and $\mathrm{KCl}$ concentrations. This may be attributed to the resistance of this strain to salt, as revealed by our previous study on membrane characteristics using flow cytometry (Gandhi and Shah, 2015). Lactobacillus casei showed the highest adhesion ability, with $91 \%$ relative adherence at $7.5 \% \mathrm{NaCl}+$ $\mathrm{KCl}(1: 1)$, which is higher than that of Lb. acidophilus $(82 \%$, at $7.5 \% \mathrm{NaCl}+\mathrm{KCl})$ and B. longum $(79 \%$, at $2.5 \% \mathrm{NaCl}+\mathrm{KCl}$ ). It has been shown that the cell surface proteins of bacteria can contribute to in vitro adhesion ability to intestinal cells (Kos et al., 2003; Buck et al., 2005). These surface proteins, adhesins, are responsible for adherence of bacteria to intestinal mucus layer. Our previous findings using Fourier transform infrared spectroscopy revealed changes occurring in the surface functional groups of bacteria, particularly in the amide regions, when subjected to varying salt concentrations (Gandhi et al., 2014). These shifts in the Fourier transform infrared spectra are indicative of the changes occurring in cell surface proteins, and could possibly be contributing to the changes in adhesion ability of the bacteria to Caco-2 cells.

\section{CONCLUSIONS}

Bacteria respond to environmental stress by altering the nature of the cell wall or by accumulation of compatible solutes within the cell. Different bacteria have different genetic makeup, thus conferring a variation in their tolerance and adaptability to stress. This study revealed that damage to bacterial cell membrane occurred as a result of high level of salt (10.0\%), and the effects of these changes were observed in the adhesion ability of the bacteria to human intestinal epitheliallike Caco-2 cells. All 3 bacteria responded to salt stress mainly by increasing the unsaturated FA content. Interestingly, the adhesion ability of stressed bacteria was reduced at high salt concentrations (7.5 and 10.0\%), possibly due to changes in the surface functional proteins. The membrane FA and phospholipids were altered in response to salt stress; however, it was revealed that substitution with $\mathrm{KCl}$ had a protective effect on the bacterial membrane.

\section{ACKNOWLEDGMENTS}

The authors thank W. S. Lee, Electron Microscope Unit, at Queen Mary's Hospital, The University of Hong Kong, for his help in preparing the TEM sections, and Wai Hung Sit (Nutrition Research Laboratory, The University of Hong Kong) for providing training on cell line work.

\section{REFERENCES}

Albarracin, W., I. C. Sanchez, R. Grau, and J. M. Barat. 2011. Salt in food processing; usage and reduction: A review. Int. J. Food Sci. Technol. 46:1329-1336.

Ayyash, M. M., and N. P. Shah. 2011. Effect of partial substitution of $\mathrm{NaCl}$ with $\mathrm{KCl}$ on proteolysis of halloumi cheese. J. Food Sci. 76:C31-C37.

Beales, N. 2004. Adaptation of microorganisms to cold temperatures, weak acid preservatives, low $\mathrm{pH}$, and osmotic stress: A review. Compr. Rev. Food Sci. Food Saf. 3:1-20.

Bermudez-Brito, M., J. Plaza-Diaz, S. Munoz-Quezada, C. GomezLlorente, and A. Gil. 2012. Probiotic mechanisms of action. Ann. Nutr. Metab. 61:160-174.

Buck, B. L., E. Altermann, T. Svingerud, and T. R. Klaenhammer. 2005. Functional analysis of putative adhesion factors in Lactobacillus acidophilus NCFM. Appl. Environ. Microbiol. 71:8344-8351.

Buemi, M., M. Senatore, F. Corica, C. Aloisi, A. Romeo, D. Tramontana, and N. Frisina. 2002. Diet and arterial hypertension: Is the sodium ion alone important? Med. Res. Rev. 22:419-428.

Chatterjee, M. T., S. A. Khalawan, and B. P. G. Curran. 2000. Cellular lipid composition influences stress activation of the yeast general stress response element (STRE). Microbiology 146:877-884.

Csonka, L. N., and A. D. Hanson. 1991. Prokaryotic osmoregulationGenetics and physiology. Annu. Rev. Microbiol. 45:569-606.

Dickman, S. R., and C. M. Proctor. 1952. Factors affecting the activity of egg white lysozyme. Arch. Biochem. Biophys. 40:364-372.

Falkow, S., R. R. Isberg, and D. A. Portnoy. 1992. The interaction of bacteria with mammalian-cells. Annu. Rev. Cell Biol. 8:333-363.

Gandhi, A., Y. X. Cui, M. Y. Zhou, and N. P. Shah. 2014. Effect of KCI substitution on bacterial viability of Escherichia coli (ATCC 25922) and selected probiotics. J. Dairy Sci. 97:5939-5951.

Gandhi, A., and N. P. Shah. 2015. Effect of salt on cell viability and membrane integrity of Lactobacillus acidophilus, Lactobacillus casei and Bifidobacterium longum as observed by flow cytometry. Food Microbiol. 49:197-202.

Graeme-Cook, K. A., G. May, E. Bremer, and C. F. Higgins. 1989. Osmotic regulation of porin expression: A role for DNA supercoiling. Mol. Microbiol. 3:1287-1294.

Guerzoni, M. E., R. Lanciotti, and P. S. Cocconcelli. 2001. Alteration in cellular fatty acid composition as a response to salt, acid, oxidative and thermal stresses in Lactobacillus helveticus. Microbiology $147: 2255-2264$

Gurtovenko, A. A., and I. Vattulainen. 2008. Effect of $\mathrm{NaCl}$ and $\mathrm{KCl}$ on phosphatidylcholine and phosphatidylethanolamine lipid membranes: Insight from atomic-scale simulations for understanding salt-induced effects in the plasma membrane. J. Phys. Chem. B 112:1953-1962.

Heaney, R. P. 2006. Role of dietary sodium in osteoporosis. J. Am. Coll. Nutr. 25(Suppl):271S-276S.

Kimoto-Nira, H., M. Kobayashi, M. Nomura, K. Sasaki, and C. Suzuki. 2009. Bile resistance in Lactococcus lactis strains varies with cellular fatty acid composition: analysis by using different growth media. Int. J. Food Microbiol. 131:183-188.

Kos, B., J. Suskovic, S. Vukovic, M. Simpraga, J. Frece, and S. Matosic. 2003. Adhesion and aggregation ability of probiotic strain Lactobacillus acidophilus M92. J. Appl. Microbiol. 94:981-987.

Kotchen, T. A. 2005. Contributions of sodium and chloride to $\mathrm{NaCl}$ induced hypertension. Hypertension 45:849-850.

Lee, A. G. 2004. How lipids affect the activities of integral membrane proteins. Biomchim. Biophys. Acta 1666:62-87.

Lee, Y. K., K. Y. Puong, A. C. Ouwehand, and S. Salminen. 2003. Displacement of bacterial pathogens from mucus and Caco-2 cell surface by lactobacilli. J. Med. Microbiol. 52:925-930.

Lewis, R. N., and R. N. McElhaney. 2000. Surface charge markedly attenuates the nonlamellar phase-forming propensities of lipid bilayer membranes: Calorimetric and (31)P-nuclear magnetic resonance studies of mixtures of cationic, anionic, and zwitterionic lipids. Biophys. J. 79:1455-1464.

López, C. S., H. Heras, H. Garda, S. Ruzal, C. Sanchez-Rivas, and E. Rivas. 2000. Biochemical and biophysical studies of Bacillus sub- 
tilis envelopes under hyperosmotic stress. Int. J. Food Microbiol. $55: 137-142$.

Massey, L. K. 2005. Effect of dietary salt intake on circadian calcium metabolism, bone turnover, and calcium oxalate kidney stone risk in postmenopausal women. Nutr. Res. 25:891-903.

McLaggan, D., J. Naprstek, E. T. Buurman, and W. Epstein. 1994. Interdependence of $\mathrm{K}+$ and glutamate accumulation during osmotic adaptation of Escherichia coli. J. Biol. Chem. 269:1911-1917.

McMahon, M. A. S., D. A. McDowell, and I. S. Blair. 2007. The pattern of pleiomorphism in stressed Salmonella virchow populations is nutrient and growth phase dependent. Lett. Appl. Microbiol. 45:276-281.

Murga, M. L. F., G. M. Cabrera, G. F. de Valdez, A. Disalvo, and A. M. Seldes. 2000. Influence of growth temperature on cryotolerance and lipid composition of Lactobacillus acidophilus. J. Appl. Microbiol. 88:342-348.

Nzai, J. M., and A. Proctor. 1998. Phospholipids determination in vegetable oil by thin-layer chromatography and imaging densitometry. Food Chem. 63:571-576.

Oliveira, D. L., A. Costabile, R. A. Wilbey, A. S. Grandison, L. C. Duarte, and L. B. Roseiro. 2012. In vitro evaluation of the fermentation properties and potential prebiotic activity of caprine cheese whey oligosaccharides in batch culture systems. Biofactors 38:440-449.

Özbalci, C., T. Sachsenheimer, and B. Brugger. 2013. Quantitative analysis of cellular lipids by nano-electrospray ionization mass spectrometry. Methods Mol. Biol. 1033:3-20.

Parkar, S. G., D. E. Stevenson, and M. A. Skinner. 2008. The potential influence of fruit polyphenols on colonic microflora and human gut health. Int. J. Food Microbiol. 124:295-298.

Pianetti, A., M. Battistelli, B. Citterio, C. Parlani, E. Falcieri, and F. Bruscolini. 2009. Morphological changes of Aeromonas hydrophila in response to osmotic stress. Micron 40:426-433.
Plant, L. J., and P. L. Conway. 2002. Adjuvant properties and colonization potential of adhering and non-adhering Lactobacillus spp. following oral administration to mice. FEMS Immunol. Med. Microbiol. 34:105-111.

Rakhuba, D., G. Novik, and E. S. Dey. 2009. Application of supercritical carbon dioxide $(\mathrm{scCO}(2))$ for the extraction of glycolipids from Lactobacillus plantarum B-01. J. Supercrit. Fluids 49:45-51.

Sambuy, Y., I. Angelis, G. Ranaldi, M. L. Scarino, A. Stammati, and F. Zucco. 2005. The Caco-2 cell line as a model of the intestinal barrier: Influence of cell and culture-related factors on Caco-2 cell functional characteristics. Cell Biol. Toxicol. 21:1-26.

Sasser, M. 1990. Identification of bacteria by gas chromatography of cellular fatty acids. Microbial ID Technical Note, 101. Microbial ID, Newark, DE.

Szalontai, B., Y. Nishiyama, Z. Gombos, and N. Murata. 2000. Membrane dynamics as seen by fourier transform infrared spectroscopy in a cyanobacterium, Synechocystis PCC 6803. The effects of lipid unsaturation and the protein-to-lipid ratio. Biochim. Biophys. Acta 1509:409-419.

Török, Z., I. Horvath, P. Goloubinoff, E. Kovacs, A. Glatz, G. Balogh, and L. Vigh. 1997. Evidence for a lipochaperonin: Association of active protein-folding GroESL oligomers with lipids can stabilize membranes under heat shock conditions. Proc. Natl. Acad. Sci. USA 94:2192-2197.

Wang, Y., J. Delettre, A. Guillot, G. Corrieu, and C. Beal. 2005. Influence of cooling temperature and duration on cold adaptation of Lactobacillus acidophilus RD758. Cryobiology 50:294-307.

Wu, C., J. Zhang, M. Wang, G. Du, and J. Chen. 2012. Lactobacillus casei combats acid stress by maintaining cell membrane functionality. J. Ind. Microbiol. Biotechnol. 39:1031-1039.

Zhao, D., and N. P. Shah. 2014. Influence of tea extract supplementation on bifidobacteria during soymilk fermentation. Int. J. Food Microbiol. 188:36-44 